\title{
MEMAHAMI PESAN AJARAN AGAMA SECARA DEWASA SALAH SATU SYARAT UNTUK MEWUJUDKAN TOLERANSI
}

\author{
Kamaluddin \\ Universitas Islam Negeri Sumatera Utara (UINSU) Medan \\ kamaluddindalimunthe2@gmail.com
}

\begin{abstract}
Abstrak
Mewujudkan toleransi baik antar umat beragama, Intern umat beragama, maupun antar umat beragama dengan pemerintah (Trilogi Kerukunan), sikap kedewasaan dalam memahami ajaran agama yang dianutnya merupakan prasyarat bagi penganut masingmasing agama. Di dalam ajaran Hindu senantiasa dituntut untuk melaksanakan sosialisasi kehidupan beragama ke arah persaudaraan dan persahabatan antara sesama manusia. Di dalam agama Budha toleransi merupakan cermin suatu kedewasaan mental dalam beragama. Sebab beragama atau mempunyai keyakinan tidak semata-mata untuk menciptakan atau membentuk seseorang untuk mengasingkan diri dari agama-agama lain. Di dalam ajaran agama Kristen sikap toleransi yaitu melihat diri orang lain sama seperti dirinya, mengasihi orang lain sama seperti mengasihi dirinya, walaupun kepada seorang musuh. Begitu juga di dalam ajaran agama Islam, agama ini sangat menekankan kepada aspek kemanusiaan (memanusiakan manusia), ia berusaha melepaskan manusia dari segala bentuk penindasan, penderitaan dan kekerasan, sehingga apabila penganut dari masingmasing agama bersifat dewasa dalam memahami ajaran agamanya masing-masing, maka akan diharapkan bahwa konfik Intrn Umat Beragama, Antar Umat Beragama dan Antar Umat Beragama dengan Pemerintah dapat dihindari.
\end{abstract}

Kata Kunci : Ajaran Agama, Toleransi

\begin{abstract}
Realizing tolerance (tasammuh), both among religious communities, interns of religious communities, as well as between religious communities and the government (Harmony Trilogy), an attitude of maturity in understanding the teachings of the religion it adopts is a prerequisite for adherents of each religion. In Hinduism it is always demanded to carry out the socialization of religious life toward brotherbood and friendship between fellow buman beings. In Buddhism tolerance is a reflection of mental maturity in religion. Because religion or belief is not merely to create or shape someone to isolate themselves from other religions. In the teachings of Christianity the attitude of tolerance is seeing others as themselves, loving others as loving themselves, even to an enemy. Likewise in the teachings of Islam, this religion emphasizes the buman aspect (bumanizing bumanity), it seeks to release people from all forms of oppression, suffering and violence, so that if the adherents of each religion are mature in understanding the teachings of their respective religions, it will be expected that the conflict between the Interreligious Beliefs, Interfaith Religion and Interfaith Religion with the Government can be avoided.
\end{abstract}

Keywords: Religious Teachings, Tolerance 


\section{Pendahuluan}

Mungkin semua umat beragama sepakat bahwa kehadiran agama dalam kehidupan manusia adalah sebagai guru spritual yang dapat memberikan kenyamanan, ketenangan batin, kebahagiaan dan kedamaian dalam menjalani kehidupannya, sebab tidak ada ajaran agama yang menganjurkan kepada pengikutnya untuk melakukan penindasan, peperangan, permusuhan terhadap orang lain.

Karenanya dalam mewujudkan toleransi (tasammub), baik antar umat beragama, Intern umat beragama, maupun antar umat beragama dengan pemerintah (Trilogi Kerukunan), sikap kedewasaan dalam memahami ajaran agama yang dianutnya merupakan prasyarat bagi penganut masing-masing agama.

Pemilihat kata "Dewasa" dalam judul tulisan ini, dimaksudkan untuk menghindari kesalahan pahaman dari para pembaca, sehingga tidak menimbulkan kesan bahwa orang-orang yang tidak toleran dipandang sebagai orang yang tidak mampu memahami ajaran agamanya secara baik dan benar. Sebab banyak umat beragama yang mampu memahami ajaran agamanya secara baik dan benar, namun karena ketidak dewasaan cara berfikir, maka agama kerap kali dijadikan sebagai legalisasi untuk tidak bersifat toleran (tasammuh) terhadap orang lain.

Tidak dapat dipungkiri bahwa kehadiran agama-agama dalam masyarkat dan negara, pada satu sisi akan menguntungkan, sebab agama memiliki ajaran dan nilai moral yang tinggi,tetapi pada sisi lain ia juga akan merupakan sumber konflik dan penderitaan manusia, serta sumber perpecahan dunia, bila komitmen terhadap ajaran agamanya tidak sepenuhnya dilaksanakan.

Akan tetapi bila masing-masing penganut agama mampudan mau menerima eksistensi agama orang lain, maka puralitas agama, merupakan salah satu kekuatan yang dapat mewujudkan pembangunan bangsa, sebab disana akan terjadi kompetisi sehat, yang masing-masing umat berusaha membuat yang terbaik untuk menjaga kemurnian keyakinannya masing-masing, karenanya setiap umat dituntut untuk mampu memahami secara dewasa terhadap ajaran agamanya masing-masing.

Benturan atau konflik antar maupun intern umat beragama tidak dapat terhindarkan ketika pola keberagamaan yang berkembang pada masing-masing penganut agama yang ada masih menonjolkan nuansa formalisme yang kering dengan nilai-nilai spritual, etika dan moralis. Sedangkan nilai-nilai substansial dari ajaran agama yang bersifat inklusif, moderat, toleran dan kasih sayang antar sesama tidak pernah tersintuh sama sekali, bahkan yang mencuat kepermukaan 
hanyalah truth claim dari masing-masing kelompok, akhirnya agama terseret ke arena wilayah konflik sekaligus menjadikannya sebagai alat legitimasi untuk melakukan kekerasan kepada orang atau kelompok lain.

Menyikapi hal ini, maka kepada semua penganut agama, teristimewa bagi tokoh-tokoh agama yang dipandang sebagai orang yang memiliki kharismatik bagi umatnya masing-masing, untuk bersikap lebih arif dan bijaksana serta mampu menanamkan nilai-nilai yang terkandung dalam ajaran agamanya masing-masing secara utuh dan benar, sebab dengan cara ini penganut agama akan menemukan pada ajaran agamanya masing-masing tentang nilai-nilai kemanusiaan universal dan egalitarian. Sebab apabila dari masing-masing penganut agama mampu memahami ajaran agamanya secara dewasa, maka ia akan melahirkan manusia-manusia yang memiliki keshalehan sosial, sehingga dapat membangun sikap toleran (tasammub) dalam kemajemukan, dan pada gilirannya akan berusaha mengembangkan komunikasi dan kerjasama dalam berbagai aspek kehidupan.

\section{Ciri-Ciri Berfikir Dewasa}

Menurut psikolog, umur tidak mutlak menentukan seseorang memiliki kedewasaan baik dalam berfikir maupun bersikap, sebab ada orang yang sudah dewasa dalam usia, namun sifat dan pola pikirnya masih berada pada pola dan sikap prilaku remaja bahkan level anak-anak. Sebaliknya usia masih tergolong anak-anak, namun pola fikir dan sikapnya telah dapat digolongkan dewasa.

Untuk mengenali sikap kedewasaan dalam berfikir adalah hal-hal atau ciri-ciri yang dapat dijadikan sebagai indikator, antara lain:

1. Dapat memilih dan menentukan mana yang baik yang harus dia lakukan, mana yang buruk yang semestinya dia tinggalkan.

2. Berfikir secara kritis sebelum dia melakukan sesuatu dengan alasan rasional.

3. Pribadi yang bersifat mandiri dan ramah.

4. Mampu mencari solusi dari permasalahan secara bijaksana.

5. Berhati lembut, supaya dapat menerima segalanya dengan lapang dada.

6. Siap menerima perubahan yang terjadi.

7. Lebih mementingka orang lain dari diri sendiri.

8. Sayang pada diri sendiri dan peduli terhadap orang di sekitarnya.

Bila ciri khas berfikir dewasa di atas, dihubungkan dengan memahami makna yang tersirat dari ajaran agama yang dianut/diyakini seseorang, maka dapat dipastikan umat beragama akan 
sependapat bahwa ajaran agamanya menganjurkannya untuk senantiasa berbuat kebaikan dan yang terbaik kepada orang lain.

Sebab tidak satupun agamapun yang pernah lahir di permukaan bumi ini yang tidak mengajarkan kedamaian, persatuan, persaudaraan dan kasih sayang antara sesama manusia. Karenanya tulisan ini ingin melihat ajaran dari berbagai agama yang berkembang di Indonesia mengenai konsep Tasammuh (Toleransi).

\section{Kerukunan Hidup Antar Umat Beragama Menurut Agama Hindu}

Ajaran Karma Marga dalam agama Hindu merupakan suatu ajaran yang mampu memberikan motivasi bagi penganutnya untuk tidak mementingkan diri sendiri, sebab menurut konsep Karma Marga, "perestasi yang tinggi kalau digunakan untuk kepentingan diri sendiri akan membahayakan, sebab itu kekebalan yang dimiliki oleh manusia diabdikan untuk kepentingan orang banyak" (Cudamani, tt).

Bila merujuk kepada ajaran Karma Marga, maka pengelompokan sosial yang terdapat dalam agama Hindu, tidak bertentangan dengan Kitab Weda, sebagaimana halnya dengan semboyan bangsa Indonesia "Bhinneka Tunggal Ika".

Sistem pengelompokan masyarakat kepada empat kategori (tipe) yang terdapat di dalam agama Hindu yaitu: ilmuan dan agamawan (Brahma), politisi dan meliter (Kesatria), pedagang dan wira swasta (waisya) dan kaum buruh (sudra), namun kesemuanya itu merupakan anggota badan semesta (cosmic Being), artinya bahwa Brahmana Kahatria, Waisya dan Sudra dalam istilahfalsafahnya, sekalipun berbeda kualitas dan tugas, akan tetapi memiliki semangat yang sama, dengan perkataan lain, walau berbilang tetapi satu (Adwita sosial) (Wayan Sadya, 1990 : 21).

Bertitik tolak dari ajaran Adwita sosial, maka tidak dapat dipungkiri bahwa bumi yang dihuni oleh umat manusia tentunya memiliki bahasa yang berbeda-beda, ritus agama yang berlainan (Dharma) sesuai dengan keadaan tempat tinggal (Atharwa Weda), oleh karenanya, manusia tidak dapat tidak harus berhubungn dengan penganut agama-agama lain.

Berdasarkan ajaran adwita sosial, maka dalam agama Hindu dikembangkan ajaran etika atau tatasusila yang berdasarkan kepada "Tattawam Asi”, yaitu mengasihi orang lain seperti diri sendiri (Harsa Swabodhi, 1980 : 99), dengan dasar ajaran ini (Tattawam Asi), maka dalam agama Hindu etika berkedudukan sebagai pengetahuan tata susila, mengatur tingkah laku umat manusia agar tidak bertindak hal-hal yang menyimpang dari sabda Tuhan. Oleh kaenanya Etika merupakan 
bahagian yang tidak dapat dipisahkan dari Hinduisme, sebab ia mengatur prilaku antara manusia dengan manusia, manusia dengan Tuhan dan manusia dengan alam.

Menurut ajaran Hindu, untuk dapat melaksanakan ajaran Tattawan Asi dengan baik, maka ada tiga hal dasar prilaku yang harus dikendalikan dan disesuaikan seseorang yaitu:

a. Mana Cika yaitu prilaku pikiran yang baik

b. Vacika adalah dasar prilaku ucapan, perkataan yang baik

c. Kayika yaitu dasar prilaku perbuatan yang baik (Harsa Swabodhi, 1980)

Kemudian Rig Weda, Y.26. 2) dijelaskan bahwa "semoga seluruh makhluk memandang aku dengan mata bersahabat; semoga memandang satu sama lain dengan mata bersahabat" (Ayan Sadya, $1990: 209)$.

Dari kutipan ayat-ayat Weda di atas, maka umat yang beragama Hindu menjadikannya sebagai pedoman etika dan moral di dalam mengemban tugas dan kewajibannya masing-masing dalam kerangka kehidupan beragama, bermasyarakat, berbangsa dan bernegara dalam mewujudkan tujuan pembangunan nasional yang berdasarkan Pancasila dan UUD 1945.

Dengan berpedoman kepada ajaran Tattawam Asi, maka umat Hindu senantiasa dituntut untuk melaksanakan sosialisasi kehidupan beragama ke arah persaudaraan dan persahabatan antara sesama manusia, sebab hakikatnya bersumber dari yang satu (yang Maha Kuasa, Penakdir segala ciptaan) yang diwujudkan dalam bentuk kerukunan hidup umat beragama, baik intern umat agama, antar umat beragama, maupun antar umat beragama dengan pemerintah.

dengan demikian, menurut umat Hindu pengamalan Dharma Agama tidak boleh menyimpang dari petunjuk pustaka suci Weda, oleh karena itu sosialisasi dan inkulturisasi nilainilai luhur agamanya diarahkan agar setiap umat Hindu dapat mengamalkan ajaran agamanya secara benar, bulat dan utuh di tengah-tengah kehidupan bermasyarakat, berbangsa dan bernegara.

\section{Kerukunan Hidup Antar Umat Beragama Menurut Agama Buddha}

Secara umum toleransi adalah sebuah sifat atau sikap dalam bersosialisasi dengan orangorang lain yang berbeda faham dengan kita. Secara lebih spesifik lagi, toleransi adalah sifat atau sikap menghargai pendirian orang lain yang berbeda dari pendirian kita sendiri. Dalam hubungan ini, toleransi beragama bermakna sifat atau sikap ketika dalam menghargai agama-agama orang 
lain yang berbeda dengan agama kita. Dalam konteks Buddhis, toleransi beragama dapat dijelaskan lebih khusus lagi.

Dari sudut pandangan agama Buddha, toleransi beragama bukanlah hanya sifat atau sikap seseorang dalam menghargai agama orang lain, melainkan juga suatu kewajiban teologis. Umat Buddha dimanapun percaya bahwa toleransi beragama merupakan suatu kualitas luhur yang harus ditumbuh suburkan dalam diri umat beragama sebagai konsekwensi logis dari pelaksanaan ajaran Agama Buddha. Dengan kata lain, toleransi dilihat dari kacamata Buddhis, bukanlah suatu pilihan suka atau tidak suka, melainkan "suatu kewajiban moral dan etis kita terhadap para penganut agama lain" (Harliman, tt).

Dapat ditambahkan bahwa, toleransi beragama menurut agma Buddha adalah kualitas yang dapat dimiliki seseorang setelah ia mampu mempraktekkan Brahma Vihara, empat keadaan batin yang luhur. Tampa kemampuan mengimplementasikan keempat keadaan batin luhur tersebut, seorang Buddhis belum dapat dikatakan memiliki sifat toleransi yang hakiki sebelum ia memiliki sikap batin tersebut. Keempat sikap batin tersebut ialah:

1. Metta atau Metri yaitu cinta kasih semesta yang tidak mengenal batas cakrawala, cinta kasih bagi semua.

2. Karuna yakni kasih sayang yang tidak terbatas, kasih sayang yang tidak mengenal batas cakrawala dan wawasan, kasih sayang bagi semuanya, tanpa perbedaan dan pilih kasih.

3. Mudita adalah perasaan sempati terhadap kebahagiaan dan kegembiraan orang lain atau simpati terhadap keberhasilan yang dimiliki orang lain dalam kehidupan ini.

4. Upekkha yaitu batin yang seimbang, selaras dan merasa bebas dari kerusakan dan kegelisahan (Oka Diputra, 1986 : 19-20).

Bertitik tolak dari keempat sikap batin seperti tersebut di atas, semangat toleransi, sebenarnya sudah dilaksanakan oleh seorang raja Buddhis yang besar yaitu Maharaja Asoka pada abad ke 3 SM di Negri India, dimana beliau sudah terlebih dahulu mendekritkan toleransi antar agama yang pertama di dunia, Dekrit tersebut dipahatkannya di atas sebuah batu cadas di sebuah lereng gunung, berbunyi sebagai berikut:

"Bila kita menghormati agama kita sendiri, janganlah kita lalu mencemoohkan dan menghina agama lain, seharusnya kita menghargai pula agama-agama lainnya, dengan demikian agama kita akan menjadi berkembang, disamping kita juga memberikan bantuan bagi agama-agama lainnya" (Hasa Swabodhi, 1980 : 31). 
Dari beberapa ayat yang telah dikutip di atas, maka dalam agama Buddha terlihat ada upaya untuk mentekankan bagi penganutnya untuk saling hormat menghormati sesama manusia, walaupun bagi orang yang tidak sekeyakinan dengan kita, sebab menurut Buddha tidak sepantasnya seseorang yang mempunyai keyakinan (agama) yang dia anggap paling benar, lantas tidak memberi penghargaan bagi agama (keyakinan) orang lain.

Oleh karena itu, menurut umat Buddha, toleransi merupakan cermin suatu kedewasaan mental dalam beragama. Sebab beragama atau mempunyai keyakinan tidak semata-mata untuk menciptakan atau membentuk seseorang untuk mengasingkan diri dari agama-agama lain, tetapi ajaran agama menurut Buddha memberikan dorongan untuk menjalin hubungan-hubungan untuk semua orang, bahkan semua makhluk hidup dalam rangka menjalankan prinsip-prinsip ajaran agamanya yang luhur, sehingga ajaran agama tersebut dapat menumbuh suburkan rasa kesetiyakawanan terhadap semua umat manusia.

\section{Kerukunan Hidup Antar Umat Beragama Menurut Agama Kristen}

Demikian juga halnya dengan agama Kristen tercermin dalam Doktrin Cinta. Sebab bila diperhatikan ayat-ayat Injil, di sana akan ditemui beberapa ayat yang pada hakikatnya menganjurkan agar manusia saling menghargai, kasih mengasihi antara sesamnya, yang bila dikaitkan dengan tujuan dari Kerukunan Antar Umat Beragama, maka dapat dikatakan ayat-ayat Injil tersebut sangat membantu untuk mewujudkan/mendukung terciptanya kerukunan hidup antar umat beragama. Ayat-ayat dimaksud antara lain, seperti terdapat dalam Injil Matius, 22:3639 ;

Guru, hukum manakah yang terutama dalam hukum Taurat,

Jawab Yesus kepdanya; "Kasihilah Tuhan, Allahmu, dengan segenap hatimu dan dengan segenap jiwamu, dan dengan segenap akal budimu.

Itulah hukum yang pertama dan utama.

Dan hukum yang kedua, yang sama dengan itu ialah: kasihilah sesama, sesama manusia seperti dirimu sendiri (Al-Kitab, $1982: 33$ ).

Kemudian dalam Injil Lukas, 6:27 dijelaskan:

Tetapi kepadamu, yang mendengar Aku berkata, kasihilah musuhmumu, berbuat baiklah kepada orang yang membencii kamu.

Tetapi kepada kamu, mintalah berkat bagi orang yang mengutuk kamu, berdoalah bagi orang yang membencii kamu.

Barangsiapa yang menampar pipmu yang satu, berikanlah juga kepadanya pipimu yang lain, dan barangsiapa yang mengambil jubahmu, biarkan juga ia mengambil bajumu.

Bila dilihat kutipan-kutipan ayat Injil di atas, maka dapat dikatakan bahwa ayat Injil tersebut memberi isyarat bahwa ajaran Kristen sangat mendukung terwujudnya toleransi Antar 
Umat Beragama, sebab ayat-ayat Injil di atas menuntut umatnya untuk melihat umat lain, sama seperti mereka, melihat diri orang lain sama seperti dirinya, mengasihi orang lain sama seperti mengasihi dirinya, walaupun kepada seorang musuh.

Dengan demikian dapat ditambahkan, seandainya umat Kristiani berpedoman kepada ajaran kitab sucinya, maka tidak ada alasan kuat untuk tidak menghargai, mengasihi dan saling menghormati antara satu dengan lainnya.Berdasarkan ayat-ayat Injil seperti yang telah dikemukakan di atas, seharusnya umat Kristen terpanggil dan terbuka untuk berkonsultasi, tukar menukar informasi, diskusi, mengadakan dialog dan bekerja sama dengan sesama umat beragama menuju cita-cita pembangunan nasional, mencapai masyarakat adil dan makmur berdasarkan Pancasila dan Undang-Undang Dasar 1945.

\section{Kerukunan Hidup Antar Umat Beragama Menurut Agama Islam}

Islam merupakan agama yang terakhir diturunkan oleh Tuhan, sebagai agama terakhir, disamping ia merupakan penengah (wasathah) juga, merupakan saksi bagi umat terdahulu. Islam membawa ajaran yang syarat dengan kedamaian, sesuai dengan tuntutan fitrah manusia, oleh karenanya Islam memerintahkan umatnya "agar umatnya berpegang teguh kepada ajaran kontiunitas itu, dengan beriman kepada semua para nabi dan rasul Tuhan, tanpa kecuali dan tanpa membeda-bedakan antara mereka baik yang disebut dalam kitab suci maupun yang tidak disetkan (Nurcholish Madjid, 1993 : 90), inilah yang digambarkan oleh Allah dalam surat Al-Baqarah ayat 136:

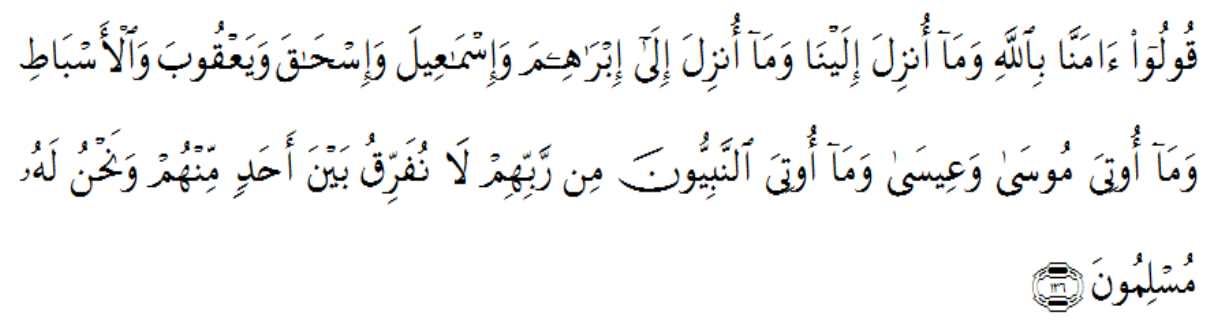

"Katakanlah (bai orang-orang mukmin): Kami beriman kepada Allab dan apa yang diturunkan kepada kami, dan apa yang diturunkan kepada Ibrahim, Ismail, Ishaq, Ya'kub dan Isa serta apa yang diberikan kepada Nabi-Nabi dari Tubannya. Kami tidak membeda-bedakan seorangpun diantara mereka dan kami hanya tunduk patub kepada-Nya".

Ayat di atas menggambarkan bahwa Islam sebagai agama terakhir, merupakan titik kulminasi dari proses pertumbuhan dan perkembangan agama-agama dalam garis kontiunitas, oleh sebab itu secara implisit Islam telah memberi kesaksian atau mengakui akan hak agamaagama lain, pengakuan akan hak agama-agama lain itu dengan sendirinya merupakan dasar bagi 
terwujudnya tasammuh/toleransi, sebab pengakuan akan keberadaan orang lain merupakan syarat mutlak untuk terbentuknya saling hormat menghormati antara satu dengan lainnya.

Karenanya Islam memandang bahwa keragaman kepercayaan merupakan sunnatullah atau ketetapan Tuhan yang tidak berubah-ubah. Hal ini dijelaskan Allah dalam surat al-Maidah ayat 44 s/d 50;

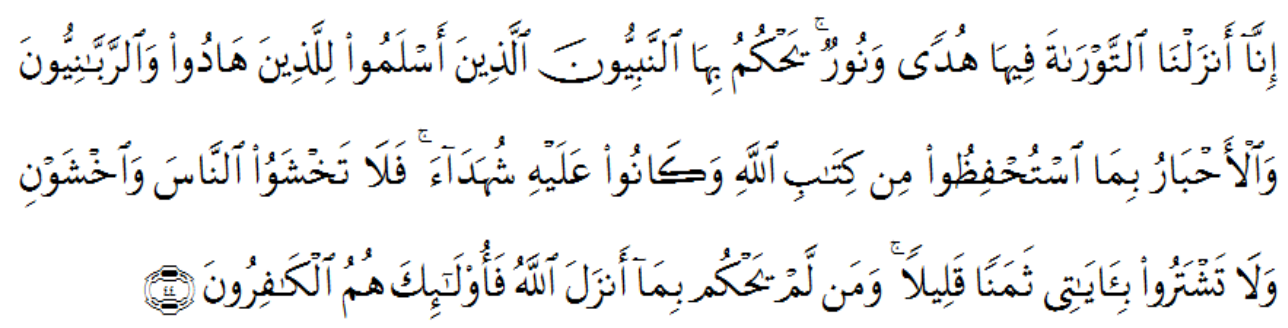

Bertitik tolak dari ayat-ayat di atas, maka Islam tidak pernah dan tidak mentolerir terjadinya pemaksaan-pemaksaan terhadap agama, hal ini diisyaratkan al-Quran pada surat alBaqarah ayat 256;

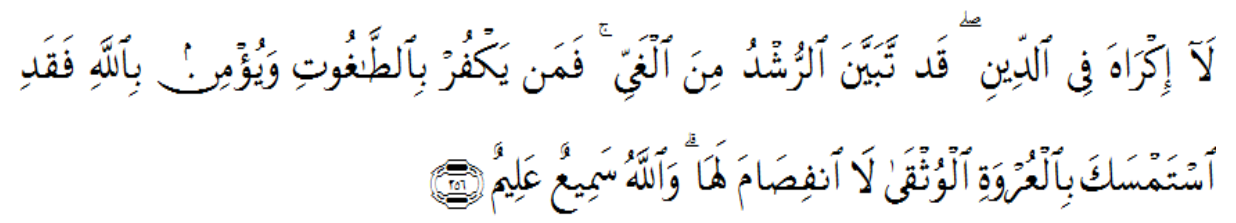

"Tidak ada paksaan untuk (memasuki) agama (Islam) sesunggubnya telab jelas jalan yang benar daripada jalan yang sesat. Karena itu barangsiapa yang ingkar kepada thagbut dan beriman kepada Allah, maka sesungguhnya ia telah berpegang kepada bubul tali yang amat kuat yang tidak akan putus. Dan Allah Maba mendengar lagi Maha mengetabui".

Sikap keterbukaan dalam Islam menjadikan Islam menjadi agama yang amat menghargai keyakinan ajaran agama lain, akibat dari rasa penghargaan itu, maka Islam bukan hanya membenarkan bahkan melarang para penganutnya untuk memaki sembahan-sembahan (keyakinan) agama lain. Disinilah mungkin sifat tasammuh/toleransi yang mendasar yang ditunjukkan Islam terhadap agama-agama lain. Hal ini dijelaskan Allah dalam surat al-an'Am ayat 108 ;

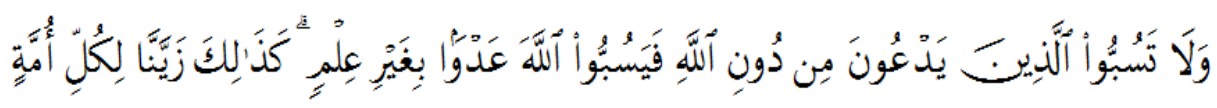

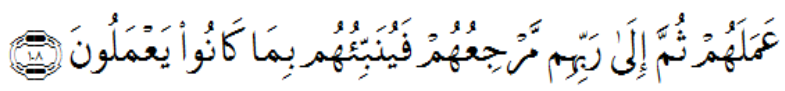


'Dan janganlah kamu memaki sembahan-sembahan yang mereka sembah selain Allah, karena mereka nanti akan memaki Allah dengan melampaui baras tanpa pengetahuan. Demikianlab Kami jadkan setiap umat menganggap baik pekerjaan mereka. Kemudia kepada Tuban merekalah kembali mereka, lalu Dia memberitakan kepada mereka apa yang dabulu mereka kerjakan”.

Ayat-ayat yang telah dikutif di atas, memberikan penjelasan bahwa Islam mempunyai sifat dan sikap terbuka bagi agama-agama lain, keterbukaan Islam terhadap agama lain memberi dampak yang amat positif terhadap perilaku umatnya dalam hubungannya dengan agama-agama lain, hal ini juga dijelaskan Allah dalam surat al-Mumtahanah ayat 8;

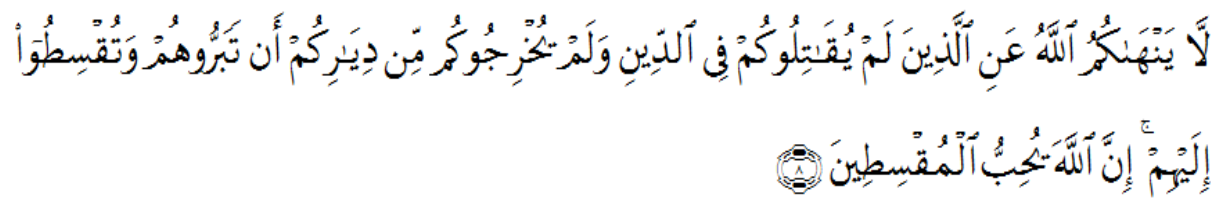

"Allah tiada melarang kamu untuk berbuat baik dan berlaku adil terhadap orang-orang yang tiada memerangi kamu karena agama dan tidak. (pula) mengusir kamu dari negerimu. Sesungguhnya Allah menyukai orang-orang yang berlaku adil”.

Sejalan dengan penjelasan-penjelasan di atas, maka Islam mempunyai kesadaran, bahwa disamping manusia mempunyai derajat yang sama, juga mempunyai kesadaran persaudaraan, bukan hanya terhadap orang yang sekeyakinan dengannya.Tetapi umat manusia secara keseluruhan, sebagaimana yang dikemukakan oleh Prof. Dr. H. M. Ridwan Lubis, dalam sebuah makalahnya yang disampaikan dalam pertemuan agama-agama di Asrama Pangkalan Masyhur Medan, bahwa dalam ajaran Islam rasa kesadaran persamaan derajat serta persaudaraan yang tinggi bukan hanya kepada seagama (ukhwah Islamiyah) dan saudara sesama umat manusia (ukhwah basyariyah) dan lebih luas dari itu saudara sebangsa (ukhwah wathaniyah).

Adanya kesadaran terhadap rasa persaudaraan sesama umat manusia didasarkan kepada keyakinan bahwa manusia adalah karya puncak Allah SWT, oleh karena manusia sebagai karya puncak yang dilukiskan dalam surat at-Tin sebagai "ahsana taqwin”, maka dengan sendirinya manusia harus selalu didorong untuk berikrar pada dirinya untuk berbuat yang baik (al-shalah) dan yang terbaik (al-ashlas) dalam kehidupannya. Dan karena itu, seorang muslim harus selalu menghindarkan diri dari perbuatan yang mengakibatkan desintegrasi sosial atau juga disharmoni, karena misi syari'at Islam adalah untuk menjadikan kesinambungan (al-tawazun) dalam kehidupan(Ridwan Lubis, tt : 6).

Menyikapi ajaran agama-agama yang telah dikemukakan di atas, maka kepada semua penganut agama, teristimewa bagi tokoh-tokoh agama yang dipandang sebagai orang yang memiliki kharismatik bagi umatnya masing-masing,untuk bersikap dewasa dalam memahami 
makna yang tersirat dalam ajaran masing-masing agama.Sehingga dengan demikian tokoh-tokoh agama bisa lebih arif dan bijaksana serta mampu menanamkan nilai-nilai yang terkandung dalam ajaran agamanya masing-masing secara utuh dan benar.

Sebab dengan cara ini penganut agama akan menemukan pada ajaran agamanya masingmasing tentang nilai-nilai kemanusiaan universal dan egalitarian. Sebab apabila dari masingmasing penganut agama mampu memahami ajaran agamanya secara konprehensif, maka ia akan melahirkan manusia-manusia yang memiliki keshalehan sosial, sehingga dapat membangun sikap tasammuh/toleran dalam kemajemukan, dan pada gilirannya akan berusaha mengembangkan komunikasi dan kerjasama dalam berbagai aspek kehidupan.

Dalam pada itu dapat dikatakan bahwa missi yang diemban oleh Nabi Muhammad saw, banyak terkait dengan missi kemanusiaan. Artinya agama ini sangat menekankan kepada aspek kemanusiaan (memanusiakan manusia), ia berusaha melepaskan manusia dari segala bentuk penindasan, penderitaan dan kekerasan, sehingga apabila penganut dari masing-masing agama bersifat dewasa dalam memahami ajaran agamanya masing-masing, maka akan diharapkan bahwa konfik Intrn Umat Beragama, Antar Umat Beragama dan Antar Umat Beragama dengan Pemerintah dapat dihindari.

\section{Penutup}

Pemilihat kata "Dewasa" dalam judul tulisan ini, dimaksudkan untuk menghindari kesalahan pahaman dari para pembaca, sehingga tidak menimbulkan kesan bahwa orang-orang yang tidak toleran dipandang sebagai orang yang tidak mampu memahami ajaran agamanya secara baik dan benar. Sebab banyak umat beragama yang mampu memahami ajaran agamanya secara baik dan benar, namun karena ketidak dewasaan cara berfikir, maka agama kerap kali dijadikan sebagai legalisasi untuk tidak bersifat toleran (tasammuh) terhadap orang lain. Bila ciri khas berfikir dewasa, dihubungkan dengan memahami makna yang tersirat dari ajaran agama yang dianut/diyakini seseorang, maka dapat dipastikan umat beragama akan sependapat bahwa ajaran agamanya menganjurkannya untuk senantiasa berbuat kebaikan dan yang terbaik kepada orang lain.

Sebab tidak satupun agama pun yang pernah lahir di permukaan bumi ini yang tidak mengajarkan kedamaian, persatuan, persaudaraan dan kasih sayang antara sesama manusia. Karenanya tulisan ini ingin melihat ajaran dari berbagai agama yang berkembang di Indonesia mengenai konsep Tasammuh (Toleransi). 
Di dalam agama Budha toleransi merupakan cermin suatu kedewasaan mental dalam beragama. Sebab beragama atau mempunyai keyakinan tidak semata-mata untuk menciptakan atau membentuk seseorang untuk mengasingkan diri dari agama-agama lain. Di dalam ajaran agama Kristen sikap toleransi yaitu melihat diri orang lain sama seperti dirinya, mengasihi orang lain sama seperti mengasihi dirinya, walaupun kepada seorang musuh. Begitu juga di dalam ajaran agama Islam, agama ini sangat menekankan kepada aspek kemanusiaan (memanusiakan manusia), ia berusaha melepaskan manusia dari segala bentuk penindasan, penderitaan dan kekerasan, sehingga apabila penganut dari masing-masing agama bersifat dewasa dalam memahami ajaran agamanya masing-masing, maka akan diharapkan bahwa konfik Intrn Umat Beragama, Antar Umat Beragama dan Antar Umat Beragama dengan Pemerintah dapat dihindari.

\section{Daftar Pustaka}

Ayan Sadya, Panggilan Weda, Alih Bahasa Drs. Wayan Sadya, Dharma Sarathi, 1990.

Cudamani, Pengantar Agama Hindu Untuk Perguruan Tinggi, Yayasan Dharma Sarathi, Jakarta,tt

Departemen Agama RI, Alquran dan Terjemahnya, CV Toha Putra Semarang, 1989.

Harsa Swabodhi, MA, Pdt.,Upamana Pramana Buddha Dharma dan Hindu Dharma, Yayasan Perguruan Budaya, 1980.

, Buddha Dharma Pelbagai Yana, B. P. Yayasan Pendidikan Buddha Dharma.

Harliman, Menuju Peningkatan Kerukunan Hidup Beragama, Disampaikan Pada Musyawarah Cendikiawan Antar Agama Provinsi Sumatera Utara.

Madjid, Nurcholish,Islam Doktrin dan Peradaban Sebuah Telaah Kritis Tentang Keimanan, Kemanusiaan dan Kemerdekaan, Yayasan Wakaf Para Madina, 1993.

Oka Diputra, Dharma Nidia, BP Dharma Nusantara Bahagia Jakarta, 1986,

Lubis, M. Ridwan, Corak Pemikiran Keagamaan Yang Mendukung Terwujudnya Kerukunan Hidup Sosial Umat Beragama.

Lembaga Al-Kitab Indonesia, Al-Kitab Perjanjian Lama dn Baru, Lembaga Al-Kitab Indonesia, Jakarta, 1982.

https://www.idntinus.com, hype

https://m.zonaseni.id 